\title{
The Urgency of Religious-Blasphemy Case Arrangement in the Frame of Diversity towards National Criminal Law Reform
}

\author{
Somawijaya*, Ajie Ramdan ${ }^{* *}$ \\ DOI: https://doi.org/10.22304/pjih.v5n3.a4
}

Submitted: October 14, 2018 | Accepted: December 27, 2018

\begin{abstract}
Indonesia is an independent state with One Godly Belief based on just civilized humanity. Amid the diversity, and to guarantee togetherness within the framework of state life, the state desperately needs the formulation of common goals or ideals commonly referred to as state philosophy or state ideals, which function as grodslag philosophies and common platform for citizens in the context of state life. This diversity is recognized on the Indonesian emblem of Garuda Pancasila 'Bhinneka Tunggal Ika'. The notion of the importance of regulation regarding the criminal offense of blasphemy is the realization of the first principle in the Pancasila, namely the Belief in the One and Only God. This study analyzed the new Draft of the Criminal Code submitted by the Government to the Indonesian Parliament in mid-2015 to replace the Criminal Code that is inherited from the era of the Dutch Colonial. The new Draft of the Criminal Code contains important changes, namely the existence of reconciliation efforts and revitalization of blasphemy acts. This change becomes interesting to be examined, especially from the urgency of the existence of regulation on blasphemy in the frame of diversity and aspects of penal reform. It also explains that the issue of blasphemy is very sensitive in Indonesian society. Constitutional Court Decree Number $140 /$ PUU-VII/2009 is the foundation of the re-conception and revitalization of blasphemy in Penal Reform.
\end{abstract}

Keywords: diversity, draft of criminal code, religious blasphemy.

\section{Urgensi Pengaturan Penodaan Agama dalam Bingkai Kebhinnekaan Menuju Pembaharuan Hukum Pidana Nasional}

\begin{abstract}
Abstrak
Negara Indonesia adalah negara yang berke-Tuhanan yang Maha Esa menurut dasar kemanusiaan yang adil beradab. Di tengah keberagaman dalam suatu masyarakat untuk menjamin kebersamaan dalam kerangka kehidupan bernegara diperlukan perumusan tentang tujuan-tujuan atau cita-cita bersama yang biasa disebut sebagai falsafah kenegaraan atau staatsidee (cita negara) yang berfungsi sebagai filosofische grodslag dan commonplatforms diantara sesama warga masyarakat dalam konteks kehidupan bernegara. Keberagaman tersebut tertulis pada lambang negara Indonesia Garuda Pancasila yaitu Bhineka Tunggal lka. Pemikiran akan pentingnya pengaturan tentang tindak pidana penodaan agama karena ini merupakan pewujudan dari sila pertama dalam Pancasila.
\end{abstract}


Artikel ini menganalisis Rancangan Kitab Undang-Undang Hukum Pidana (RKUHP) yang diajukan Pemerintah ke DPR RI pada pertengahan 2015 sebagai upaya mengganti Kitab Undang-Undang Hukum Pidana (KUHP) Warisan Kolonial Belanda. RKUHP memuat perubahan yang penting, yaitu adanya upaya rekonsepsi dan revitalisasi perbuatan penodaan agama (penistaan agama). Perubahan inilah yang kemudian menarik untuk diteliti, terutama dari urgensi keberadaan perbuatan penodaan agama dalam bingkai kebhinekaan dan aspek pembaharuan hukum pidana (penal reform). Artikel ini menjelaskan bahwa permasalahan penodaan agama adalah hal yang sangat sensitif dalam masyarakat Indonesia. Putusan MK No. 140/PUU-VII/2009 menjadi dasar penyusun RKUHP melakukan rekonsepsi dan revitalisasi perbuatan penodaan agama untuk memperbaharui KUHP.

Kata kunci: kebhinekaan, RKUHP, tindak pidana penodaan agama.

\section{A. Introduction}

In mid-2015, the Government submitted a Draft of Criminal Code to the House of Representatives. This step was an attempt to replace the previous Criminal Code that is a Dutch Colonial heritage. The new draft of Criminal Code contains important changes, namely the efforts of re-conception and revitalization of blasphemy crime. Hence, the changes become interesting to be examined, especially from the urgency of the existence of religious blasphemy in the frame of diversity and aspects of penal reform.

The renewal of the criminal law can be seen from several arrangements in the draft of Criminal Code as follows. First, the draft places the acts of blasphemy in a separate chapter, Chapter VII (Criminal Actions against Religion and Religious Life). In the current Criminal Code, the acts of blasphemy are included in Chapter V (Crimes against Public Order). In the first part of the draft, three (3) articles formulate Crime against Religion. The three articles regulate the prohibition of insulting religions in Indonesia and incites, in any form, with the intention of removing beliefs in a religion that are adopted in Indonesia. The threat of imprisonment starts from two (2) to five (5) years, revocation of certain rights, and penalties with category $\mathrm{III}^{1}$ and category IV ${ }^{2}$.

Second, in the second part of the Chapter VII, three (3) articles formulate Criminal Actions on Religious Life and Worship Facilities. The three articles regulate the prohibition of disturbing, obstructing, or against the law, dissolving by means of violence, or threats of violence against worshipers who are performing worship, religious ceremonies, or religious gatherings, making noise near a building of worship at the time of worship, insulting people who are carrying out worship or insulting religious officers who are carrying out their duties, tarnishing or illegally damaging or burning buildings of worship or objects used for worship. The threat of imprisonment starts from two (2) years to five (5) years, and criminal fines with category $\mathrm{II}^{3}$, category III, and category IV.

\footnotetext{
In the new draft of Criminal Code, Category III is Rp150.000.000,00 (a hundred and fifty million rupiahs). In the new draft of Criminal Code, Category IV is Rp500.000.000,00 (five hundred millions rupiah). In the new draft of Criminal Code, Category II is Rp50.000.000,00 (fifty millions rupiahs).
} 
Amid the diversity, and to guarantee togetherness within the framework of state life, the state desperately needs the formulation of common goals or ideals commonly referred to as state philosophy or state ideals, which function as grodslag philosophies and common platform for citizens in the context of state life. In Indonesia, the philosophy is Pancasila (the five basic principles). It aims to achieve or to realize the four objectives of the state. ${ }^{4}$ The first principle of Pancasila is Belief in the One and Only God (in Indonesian: "Ketuhanan Yang Maha Esa"), which illuminates the other four principles. The realization of the principle is manifested in a just and civilized understanding of humanity. The encouragement of faith and devotion to God Almighty determines the quality and degree of humanity among human beings. Therefore, community and state life can grow healthy in a just structure of life, and thus the quality of national civilization can develop respectfully among nations. ${ }^{5}$ The regulation on the acts of blasphemy is considered important because it is the realization of the first principle of Pancasila. It means that religions are the main element of Indonesian people life. The prohibited act is a disgraceful act by not respecting religion or religious community, which can cause unrest within the community, or the religious community, including the means of worship. ${ }^{6}$

Oemar Seno Adji is the first who introduced the term 'religious offense' in 1975 through his paper entitled "The Influence of Culture and Religion on Criminal Law". Based on his paper, the religious offense referred to is in the sense of offense against religion and an offense related to religion. In its history, the idea of to include religious offenses in the Criminal Code began with a National Law Seminar I in 1963. It resulted a resolution that the inclusion of religious offenses in the forthcoming Criminal Code is needed. The reason is because of Pancasila. The first principle of Pancasila is "Belief in the One and Only God". In addition, Article 29 of the 1945 Constitution is the foundation of religious life in Indonesia. This provision is used as a justification for the inclusion of religious offenses in the Criminal Code. In the view of the early formulators, religion, in both life and legal realities, is a fundamental factor. It can be understood that these factors can be used as strong and solid foundation to include religious offenses. Religious delicts can coexist with immoral delicts and can even take elements of religion as a source of inspiration. ${ }^{7}$ The idea of the National Law Seminar finally came true with the issuance of Law Number 1/PNPS/1965 on the Prevention of Abuse and/or Religious Blasphemy. Article 4 of the Law mentions the addition of a new article in the Criminal Code: Article 156a of the Criminal Code. ${ }^{8}$

In the consideration of the Decree of the Constitutional Court Number 140/PUU$\mathrm{VII} / 2009$, Paragraph 3.61, the state is required to protect the existence of a religion that has been recognized from the possibility of abuse. According to the Court, the

Jimly Asshiddiqie, Konstitusi dan Konstitusionalisme Indonesia, Jakarta: Konpress, 2005, p. 26.

Ibid., p. 65.

Badan Pembinaan Hukum Nasional (BPHN - National Law Development Agency), Naskah Akademik RUU KUHP, Jakarta: BPHN, 2015, p. 226.

Emerson Yuntho (et.al.), Dinamika Pembaharuan KUHP dan Problematikanya, Jakarta: ELSAM \& Aliansi Nasional Reformasi KUHP, 2007, p. 20.

$8 \quad$ Ibid., p. 21. 
state has no right or authority not to recognize the existence of a religion because the state is required to guarantee and to protect the religions adopted by the people of Indonesia. The Criminal Law rules three things that must be protected: (i) individual interests; (ii) social/community interests; and (iii) state interests. In addition, sociologically, the Blasphemy Prevention Law is actually responsive because it fulfills a sense of justice according to the level of sensitivity in the very high religious attitude of the Indonesian people. The meeting of the interests of criminal law and sociological facts shows that the Blasphemy Prevention Law is still needed as a general prevention. However, the Constitutional Court, its consideration for the material test, paragraph 3.33, states that the Law Number 1/Presidential Decree of 1965 on the Prevention of Abuse and/or Blasphemy of Religion is still needed. However, the court also mentions that it needs to be corrected. Still, it is deemed as substantially relevant so that it can be used.

In September 27, 2016, Basuki Tjahaja Purnama (called Ahok), the Governor of Jakarta, deliver a speech that the video was uploaded by Buni Yani. The video is circulated on Social Media. Initially, it was sourced from the video uploaded by Jakarta Provincial Government Public Relations. In his speech, Ahok says the following sentences. ${ }^{9}$

[... So don't trust people. You keep it in your little heart that you will not choose me, right? You are deceived by using the Chapter Al Maidah 51 (a Chapter in the Quran), many kinds (of all that). It is your right, so you feel like you can choose me (in the incoming governor election) because you are afraid of going to hell, being fooled like that .. ]

In the context of Governor election, the incumbent had caused a disturbance that disrupted Public Order since many Muslims felt offended by his statement, especially Islamic scholars, who use to teach the Quran to Muslims. On October 7, 2016, Muhammadiyah's Youth Movement, Homeland Advocates, FAPA -AntiBlasphemy Forum, and Irena Handono (a female Muslim scholar) reported Ahok to the National Police Headquarters Criminal Investigation Agency (Bareskrim POLRI) ${ }^{10}$ based on Article 156a of the Criminal Code. The Indonesian 1945 Constitution guarantees the independence of Indonesian citizens to embrace their respective religions and to worship according to their religion and beliefs. Therefore, the state has an obligation to protect the religions adopted in Indonesia. Ahok, who defamed Islam, must get strict sanctions from the state.

The North Jakarta District Court has sentenced the Former Governor of Jakarta to 2 years in prison. Ahok was found guilty of blasphemy because of the statement about the Chapter Al-Maidah 51 during his visit on Pramuka Island. Not satisfied with the decision, on February 2, 2018, Ahok submitted a judicial review to the

\footnotetext{
9 Rina Atriana dan Aditya Mardiiastuti, "Hakim: Ahok Merendahkan Surat Al-Maidah 51", https://news.detik.com/berita/d-3496149/hakim-ahok-merendahkan-surat-al-maidah-51, accessed on December 2018.

10 Yantina Debora, "Kronologi Kasus Dugaan Penistaan Agama”, https://tirto.id/kronologi-kasus-dugaanpenistaan-agama-b457, accessed on November 2018.
} 
Supreme Court through his lawyer. ${ }^{11}$ On March 26, 2018, the Supreme Court (MA) rejected the judicial review. The judicial review was rejected because the reasons could not be justified. ${ }^{12}$ Therefore, Ahok's statement, in his capacity as the Governor of Jakarta, was considered to have hurt Indonesian Muslim citizens. Ahok and his supporters said there was no intention to insult Indonesian Islamic scholars and Muslims. Even the opinions and statements of the Indonesian Ulama Council (MUI), which were used as evidences were also denied by Ahok and his supporters.

Indonesia is based on Pancasila, which the first principle is Belief in the One and Only God. Therefore, religion is a very sensitive thing for the people of Indonesia. The case of Ahok's blasphemy should be followed up by the completion of the Law Number 1/PNPS/1965 on the Prevention of Abuse and/or Blasphemy of Religion. It should cover the implementation and application in practice. The law, in terms of regulations, formulations, legal rules, needs to get renewal. It is to suit the needs of the Indonesian people. The Constitutional Court Decision Number 140/PUUVII/2009 become the basis to complete the draft of Criminal Code in handling the acts of blasphemy. The Constitutional Court's decision is a guideline for the establishment of the law that is related to blasphemy specifically. Based on the background and description that has been put forward, the study focuses on the urgency to renew the acts of religious blasphemy in the new draft of Criminal Code; and the criteria and size of blasphemy in the new draft of Criminal Code according to the Constitutional Court Decision Number 140/PUU-VII/2009. The study is the study of documents. It is carried out by examining library materials or secondary data as the basic material to be examined. In practice, the study searched for the rules and the literature that are related to the problems. This study employed descriptive analytical properties. ${ }^{13}$

\section{B. Urgency to Renew Religious Blasphemy in the Criminal Code}

1. The Concept of Religious Blasphemy in the State with Belief in the One and Only God

The drafting of the new Criminal Code is based on national needs and demands for renewal and, at the same time, changing/replacing the previous Criminal Code. Therefore, it is closely related to the idea of reforming criminal law, which, in essence, is also a part of larger idea, namely the development/renewal of the national legal system. The acts of blasphemy that are regulated in the Criminal Code must be changed according to the current conditions of the people. The occurrence of Ahok's blasphemy case should be followed up by the completion of the Law Number 1/PNPS of 1965 on the Prevention of Abuse and/or Blasphemy of Religion. It can be covered by the new Criminal Code to include the implementation and

\footnotetext{
11 David Oliver Purba, "Mengapa Ahok Ajukan PK atas Vonisnya?", https://megapolitan.kompas.com/read/2018/02/26/05491211/mengapa-ahok-ajukan-pk-atas-vonisnya, accessed on March 2018.

12 David Oliver Purba, "PK Ahok Ditolak MA", https://megapolitan.kompas.com/read/2018/03/26/16581111/pkahok-ditolak-ma, accessed on March 2018.

13 Soerjono Soekanto dan Sri Mamuji, Penelitian Hukum Normatif Suatu Tinjauan Singkat, Jakarta: Raja Grafindo Pustaka, 2006, p. 13.
} 
application in practice based on the Constitutional Court Decision Number 140/PUU-VII/2009.

The basic paradigm is that Indonesia is a state with the Belief in the One and Only God and has a divine philosophy departed from a very high religious feelings of the Indonesian people. This is considered as a different thing, compared to the Western people who does not care about the issues of religion, an attitude that is formed from a long history since the renaissance era that separates the domains of the state and the religion. ${ }^{14}$ In his speech before the Investigating Agency on May 31,1945 , Supomo distinguishes an Islamic State and a state that is based on the noble ideals of the Islamic values. Supomo proposes that the newly Indonesian state should not be an Islamic state. Instead, the state uses the moral values recommended by Islam. ${ }^{15}$

Concerning the regulation of offenses on religious and beliefs in the Criminal Code, Muladi, one of the members of the Criminal Code Drafting Team, states that there are a number of basic needs that need to be bridged in the issue of regulating religious offenses as follows. ${ }^{16}$

1. Pluralistic administrative order. The diversity of religious understandings will be protected and, therefore, a legal arrangement is needed to ensure the order of diversity of Indonesian people.

2. A sense of community diversity. The law designer argues that the feeling of the community in carrying out religious issues is a benchmark for the success of a regulation. Consequently, the law is made to guarantee religious values adopted by the people.

3. Religious interests. Aside from public, attention is also given to religious institutions to develop their functions. Thus, the draft of Criminal Code is expected to be able to guarantee that religions can develop in a conducive manner.

The draft of Criminal Code provides protection for religious practice from acts of disturbing, mocking, obstructing or, against the law, dissolving people who undergoes worship, religious ceremonies, destructing places of worship, and so on. ${ }^{17}$ Religion is a private matter of each individual but, in its relation to religious freedom and harmony of religious people, the state must take the initiative to provide legal protection. Furthermore, Adji explains three views on the importance of religious protection: ${ }^{18}$

1) Friedensschutz theory, viewing "der religiosce interkon fessionelle feriede" as a legal interest that must be protected;

\footnotetext{
14 Emerson Yuntho (et.al.), op.cit., pp. 22-23.

15 Endang Saifuddin Anshari, Piagam Jakarta 22 Juni 1945 dan Sejarah Konsensus Nasional, Bandung: Penerbit Pustaka Salman ITB, 1981, p. 136.

16 Emerson Yuntho (et.al.), op.cit., p. 22.

17 Ibid., p. 38.

18 Hwian Christianto, “Arti Penting UU No. 1/PNPS/1965 Bagi Kebebasan Beragama”, Jurnal Yudisial, Vol. 6, No. 1, 2013, p. 4.
} 
2) Gefühlsschutz-theorie, to protect the sense of security as a "dasheiligste innenlebender gesammtheit", as stated by Binding; and

3) Religionsshutz-theory, put forward by Kohler and Kahl, viewing religion as a legal interest that must be secured by the state based on "das Kulturgut der Religion und der ungeheuren Idealismus, der aus ihr fürreine grösse Menge von Menschen hervorgeht."

Adji believes that Indonesia with the regulation of crimes against religion is more likely to apply Religionsshutz-theorie because the purpose of the Law Number 1/PNPS of 1965 is to secure the legal interests of the religions adopted in Indonesia. He also stresses the importance of the blasphemy rule, considering that Indonesia does not have a defense against attacks of words against God. Sudarto explains, before the Law Number 1/PNPS of 1965, many cases of blasphemy, such as, tearing and stepping on Quran, saying Prophet Muhammad "a false prophet", insulting priest for not marrying, etc. One of the most phenomenal, there was a ketoprak (Javanese traditional theater) performing a play entitled "Paus Gandrung" (a Horny Pope) and the emergence of cults that calls themselves religions but their religious practices are very deviant from the existing religious rules. The renewal of the blasphemy regulation has been initiated since 1969 through the Law Number 6 of 1969 on the annulment of laws and Government Regulations in Lieu of Law. It mentions that the material of the Law Number 1/PNPS of 1965 needs to be contained in a new law with the necessary improvements. ${ }^{19}$ Therefore, the regulation of blasphemy in the Law Number 1/PNPS of 1965 must be refined in the new draft of Criminal Code based on the first principle of Pancasila and the state must view religion as a legal interest that must be protected. The basic paradigm is that Indonesia is a state with the Belief in the One and Only God and has a divine philosophy departed from a very high religious feelings of the Indonesian people.

\section{The Importance of the Renewal of the Concept of Blasphemy in the Frame of Diversity}

Pancasila and the 1945 Constitution are the highest legal documents in the state activities. They are also seen in relation to diverse community life and market economic activities of the Indonesian people. Pancasila can be said to have a central position in Indonesian national life because it is the spirit of the constitution, a national ideology, and a national philosophy. The ideological values and the philosophy of Pancasila are functioned as sources of normative references in both formulating a system of legal norms and a system of ethical norms within the life of society, nation, and state. Pancasila functions as a source of values and norms, in both the context of the legal system, or the rule of law, and in the context of the ethical system, or rule of ethics, of the Republic of Indonesia. ${ }^{20}$

To improve the regulation, the state must refer to the Pancasila and pay attention to the diversity of the Indonesian people. This diversity must be respected

19 Ibid.

20 Jimly Asshidiqie, Gagasan Konstitusi Sosial, Jakarta: LP3ES, 2015, pp. 53-55. 
with mutual respect among the religious people in Indonesia based on the motto Bhinneka Tunggal Ika. ${ }^{21}$ Historically, The Law Number 1/PNPS/1965 is made to secure the state and society, the ideals of national revolution, and the development where the abuse or blasphemy of religion is seen as a threat to the revolution. The emergence of various new mystical/religious beliefs or organizations, which are considered contrary to the teachings and laws of religion. These new streams are seen as violating the law, breaking national unity, and tarnishing religion. Therefore, national caution is needed and it was manifested in the law. Hence, this rule is intended to prevent misuse of religious mainstream teachings, which are the teachings of scholars. In addition, this rule protects the religious peace from desecration and from the deviated teachings that harms the first principle of Pancasila. This law is intended to restrict religious cults outside the official religions. Normatively, the guarantee of freedom of religious life in Indonesia is actually quite strong. However, in its implementation, there is a feeling of being restricted in freedom of religion and belief. The freedom of religion that is recognized by the government means that if you embrace a religion outside the recognized religions, then there are effects that can reduce the civil rights of citizens. People, who have certain beliefs, can be accused of blasphemy ${ }^{22}$ because Law Number 1/PNPS/1965 on the Prevention of Abuse and/or Blasphemy of Religion was published to accommodate requests from Islamic organizations who wanted to ban the cults.

Soekarno agreed with the conservative Muslim community, assuming that almost all of cults or public beliefs were contradicted the mainstream teachings and laws of Religion. Sukarno published the Decree Number 1/PNPS/1965. The appendix to the decree describes the national situation when the provisions are made. At that time, many cult followers were accused of violating the law, breaking national unity, and tarnishing religions. Therefore, in an emergency, Sukarno issued the Blasphemy Law. Then Article 156a is inserted in the composition of the Criminal Code. ${ }^{23}$

Article 156, as the head, is intended to regulate a particular group. The punishment process will begin if a perpetrator does not heed strict warning, dissolution, or prohibition. In this case, the right to give a strict warning, dissolution, or prohibition is the Coordination Body of the Public Beliefs (Bakorpakem). Bakorpakem itself consisted of a combination of the Ministry of Religion, the Ministry of Home Affairs, the Police, the State Intelligence Agency, and religious organizations such as the MUI. Article 156a can be addressed individually. The handling model is directly processed through an examination of investigations and prosecutions in court. ${ }^{24}$

Actually, the issue of religious belief is very individually. As long as it is in its corridors, it is not a problem. Religious freedom is one of the most basic rights

21 Ahmad Jazuli, "Penyelesaian Konflik Penodaan Agama Dalam Perspektif Hukum Pidana Di Indonesia”, Jurnal De Jure, Vol. 17, Issue 3, 2017, pp. 332-333.

22 Dieqy Hasbi Widhana, "Asal-Usul Delik Penistaan Agama”, https://tirto.id/asal-usul-delik-penistaan-agamab49e, accessed on November 2018.

23 Ibid.

24 Ibid. 
among human rights since it is sourced from human dignity as God's creation. However, when an individual invites other people to carry out deviant religious rituals, or do something outside the mainstream of his beliefs and not in the capacity to talk about other religions, like the Ahok case, it is a big problem. ${ }^{25}$ According to District Court Decision Number 1537/Pid.B/2016/PN, the Defendant, Basuki Tjahaja Purnama (Ahok), was proven legally and convincingly guilty of blasphemy. The defendant had considered Al-Maidah to be a tool to deceive people or society, or Al-Maidah 51 as a source of lies and with such assumptions. According to the court, the defendant had demeaned and insulted Chapter Al-Maidah verse 51. The panel of judges declared Ahok to be proven to violate Article 156a of the Criminal Code, namely deliberately and publicly issued feelings or committed acts of hostility, abuse, or desecration of a religion. If Ahok's utterance about Al-Maidah verse 51 is not delivered in the public and only becomes a discussion in the religious circles that Ahok adheres to, it is not an act of blasphemy of Islam. Ahok does not have the competence to speak about Al-Maidah verse 51 . His opinion should be a matter of discussion in the private space.

A rule of law must be viewed from empirical applicability through three criteria for recognition, acceptance, and legal reality. The enactment of Law Number 1/PNPS/1965 based on acceptance can be seen from the community's commitment not to commit acts that are prohibited in the Law. The number of blasphemy cases is evidence that the community feels bound by the legal provisions. In addition, blasphemy cases that are occurred also prove the absence of public acceptance of the rule of law. Finally, the legal reality requires positive law to be adhered because in the formulation of complex positive laws, truth and validity are contained. The Law Number 1/PNPS/1965 is quite effective in tackling religious blasphemy. Based on these three criteria, it can be concluded that the sociological applicability of the Law Number 1/PNPS/1965 has not been achieved properly. Therefore, the legal rules need to be improved. Related to the issue of whether the regulations made in the state of emergency in valid temporarily, the legal product of the president's decree are not known in the order of Indonesian legislation. Consequently, the steps are to test the rule against the 1945 Constitution. ${ }^{26}$

Law enforcers will use the rule of law to enforce the law. The rule of law is an important instrument in law enforcement. ${ }^{27}$ Four factors greatly influence law enforcement in a democratic state. The first is the law itself, both in the substantial sense of a statutory regulation and formal law to enforce material law. The second is the professionalism of law enforcement officers. The third is adequate facilities and infrastructure. The fourth is the public perception of the law itself.

A factor that greatly influences law enforcement in a democratic state are the most important law itself. The need to renew blasphemy deeds must be completed in a form of new Criminal Code that protect all citizens of the religious state.

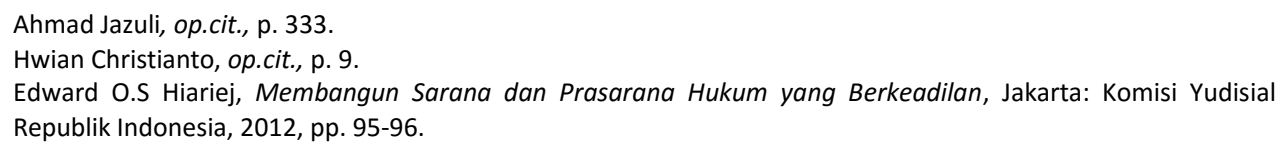


According to the Constitutional Court Decision Number 140/PUU-VII/2009, there is no right or authority for the state not to recognize the existence of a religion because the state is obliged to guarantee and to protect the religions adopted by the people of Indonesia. The Constitutional Court in its decision rejects the petition for judicial review of Articles 1 and 2 so that this provision is legally positive. Starting from the decision of the Constitutional Court, the formulation of Articles 1 and 2 should also be adopted in the new draft of Criminal Code. Believers get recognition based on the Constitutional Court Decision Number 97/PUU-XIV/2016. It is regulated in Article 61 paragraph (1) and (2), as well as Article 64 paragraph (1) and (5), of the Law Number 23 of 2006 on Population Administration in conjunction with Law Number 24 of 2013 on Population Administration. In its ruling, the Panel of Judges argued that the word 'religion' in Article 61 paragraph (1) and Article 64 paragraph (1) contradicted the 1945 Constitution and did not have the legal force to bind conditionally as long as it was not included in the belief community. ${ }^{28}$ Based on the Constitutional Court's decision, followers of cults will receive a special National Identity Card (KTP). The belief will be written on the KTP and the column of religion will change to a column of belief.

Based on the legal considerations of the Constitutional Court, the revision of the Law Number 1/PNPS of 1965 on the Prevention of Abuse and/or Blasphemy of Religion into a new draft of Criminal Code is an action that must be immediately carried out by the Government and the Parliament. Article 2 and Article 3 of the Law Number 1/PNPS of 1965 require the government, namely the Minister of Religion together with the Minister/Attorney General and the Minister of Home Affairs, or by the President of the Republic of Indonesia, to control the flow of cults that did not receive recognition from the state. The articles must be adopted in the new draft. Article 4, which becomes Article 156a of the Criminal Code, needs to redefine the forms of hostility, abuse, or desecration of a religion embraced in Indonesia, invitation not to adhere to any religion.

In revising the Law No. 1/PNPS of 1965, the Government and the House of Representatives must pay attention to the history of Indonesia, which has found a distinctive formulation of state and religious relations in the midst of the types of states in the world, namely secular, atheistic, liberal, and theocratic. The founders of this nation-state realized that the "materialist cause" of the Indonesian state was the Indonesian people. The Indonesian people since ancient times is a religious people, which acknowledged the existence of the "Essence of the Almighty", namely God. ${ }^{29}$ Therefore, the issue of blasphemy is a very sensitive in Indonesia. The Blasphemy Case of Ahok became a very valuable lesson to be addressed through the renewal of Criminal Law, especially the blasphemy law by considering the diversity of the Indonesian people and the Unitary State of the Republic of Indonesia.

28 Barratut Taqiyyan Rafie, "Akomodasi putusan MK, penganut aliran kepercayaan akan dapat KTP khusus", https://nasional.kontan.co.id/news/akomodasi-putusan-mk-penganut-aliran-kepercayaan-akan-dapat-ktpkhusus, accessed on November 2018.

29 Mohamad Sinal, Pancasila Konsensus Negara-Bangsa Indonesia, Malang: Madani, 2017, p. 51. 


\section{Criteria and Size of Blasphemy Acts Associated with Decision of MK No. 140/PUU-VII/2009}

\section{Criminal Policy Renews the Criteria and Size of Blasphemy Acts}

The efforts to renew criminal law (penal reform) in its essence include the field of reasoning policy which is a part, and closely related to law enforcement policy, criminal policy, and social policy. This means that the renewal of criminal law is essentially as follows. ${ }^{30}$

1. It is a part of the policy to renew legal substance to make law enforcement be more effective.

2. It is a part of the policy to eradicate/to overcome crime in the context of protecting community.

3. It is a part of policy to overcome social problems and humanitarian problems to achieve/support national goals: social defense and social welfare.

4. It is an effort to review and re-evaluate the main, basic, or socio-philosophical, socio-political, and socio-cultural values that policies of criminal and enforcement of criminal law all this time. It is not a reform of criminal law if the intended orientation of values and criminal law is the same as the value orientation of the Old Criminal Code.

Thus, renewal of criminal law must be taken with a policy-oriented approach and at the same time a value-oriented approach. The renewal of the Law Number 1/PNPS of 1965 must include policies to renew legal substance in order to make law enforcement more effective if a crime against religion occurs. The policy includes the eradication of crime to protect the people who adhere to religions, the restrictions of committing acts of hostility, abuse, or desecration of a religion, as well as restrictions on interpreting or deviating from the mainstream of religious teachings adopted in Indonesia. Policies to deal with social problems and humanitarian issues are to achieve/support national goals since religious issues in Indonesia are sensitive. If the law does not regulate religious blasphemy, it can cause clashes, horizontal conflicts, unrest, division, and hostility in society. Finally, the value approach is an effort to review and reassess main, basic, or sociophilosophical, socio-political and socio-cultural values that policies of criminal and legal enforcement in the cases of religious blasphemy. ${ }^{31}$

The completion of the Law Number 1/PNPS of 1965 on the Prevention of Abuse and/or Blasphemy of Religion should follow up the case of Ahok. The completion should focus on the application and the implementation in practice with an approach to criminal law policies and value approaches. ${ }^{32}$ The report made by the

30 Barda Nawawi Arief, Pembaharuan Hukum Pidana dalam Perspektif Kajian Perbandingan, Bandung: PT Citra Aditya Bakti, 2011, p. 62.

31 Barda Nawawi Arief, Kebijakan Hukum Pidana Perkembangan Penyusunan Konsep KUHP Baru, Jakarta: Kencana, 2008, p. 322.

32 Mudzakir (et.al.), Analisis dan Evaluasi Undang-Undang Nomor 1/PNPS Tahun 1965 Tentang Pencegahan Penyalahgunaan Dan/ Atau Penodaan Agama, Jakarta: Kementerian Hukum dan HAM, 2011, p. 4. 
team of the Analysis and Evaluation of the Law Number 1/PNPS of 1965 shows that there are cases of blasphemy in several areas as follows.

1. The case of the attack on Suparman's house in Cikeusik, Pandeglang, Banten, resulted in the loss of three lives of Ahmadiyah followers. It was allegedly not an act of spontaneity but by design because there were indications that the authorities omitted the violence and the massacre.

2. The case of religious blasphemy in Temanggung was perpetrated by a priest named Antonius. The perpetrator stayed at his brother's home in the Kenalan hamlet, Kranggan District, Temanggung Regency.

3. The board of the Huria Kristen Batak Protestant (HKBP) in Pondok Timur Indah said that they would continue to struggle to build a house of worship in Ciketing Asem, Mustika Jya, even though the Government of Bekasi City, West Java, had banned the project. They argued that there should no discrimination in worship.

The basic values and norms governing religion are contained in Chapter XI of the 1945 Constitution. Article 29 paragraph (1) of the 1945 Constitution states that the state is based on the Almighty God and the State guarantees the freedom of each resident to embrace their religion and worship according to their religion and the belief is contained in Article 29 paragraph (2) of the 1945 Constitution. Therefore, a Law to replace the Law Number 1/PNPS of 1965 must guarantee the independence of each residents to embrace their respective religions and to worship according to their religions and beliefs with the aim of preventing horizontal turmoil and conflict.

\section{Actions and Formulation of Religious Blasphemy offenses according to Decision of the Constitutional Court No. 140/PUU-VII/2009}

The question that appears in the Case Number 140/PUU-VII/2009 is whether the criminal threat contained in Article 1 (in conjunction with Article 3) of the Blasphemy Prevention Law Article 156a (letter a and b) of the Criminal Code, and Article 4 of the Blasphemy Prevention Law imposing a sentence of five years is a form criminalization of freedom of thought, opinion and expression in matters of religion and belief?

According to Mudzakkir, in the statement the Prosecutor ${ }^{33}$, the provision of Article 4 of the Blasphemy Prevention Law is a form of amendment to the Criminal Code, namely to add Article 156a. The criminal law norm in Article 156a, letter a, is a legal norm that determine sanctions for bad deeds, which is inherent in prohibited acts. In addition, the criminal nature arises is caused by the act of evil. The evil nature is hostility, abuse, and desecration of religion.

To be able to punish someone while fulfilling the demands of justice and humanity, there must be an act that is against the law and bear by a perpetrator. In addition to these conditions, the perpetrator must be someone who is able to bear a responsibility (Dutch: toerekeningsvatbaar). The general requirements of criminal acts are the nature of being against the law (Dutch: wederrechtelijkheid), error

33 The statement of expert, Mudzakkir, in the case Number 140/PUU-VII/2009. 
(Dutch: schuld) and ability to be responsible according to criminal law (Dutch: toerekeningsvatbaarheid). ${ }^{34}$

In addition, according to Andi Hamzah in the statement of the case expert, the blasphemy offense formulation must be in accordance with the principle of legality, nullum delictum nulla poena sine praevia lege poenali. There must be provisions of legislation before any criminal acts. A person can only be convicted if there is a law that prohibits criminal acts first, a general requirement in all states. That is, the offense is neutral, for example theft, but there are offenses that are not neutral, namely religious and decency offenses, for example about blasphemy and pornography. In China, people are free to blaspheme religion. The new Dutch Penal Code also regulates blasphemy and ideological offenses, because they are in the mind. $^{35}$

The Constitutional Court in the minute of decision, page 287, section 3.51, states that the Blasphemy Prevention Law does not prohibit someone from interpreting a religious teaching or conducting religious activities that resemble a religion adopted in Indonesia individually. The prohibition covers intentionally publicly telling, advocating or seeking public support, to make interpretations of a religion embraced in Indonesia or to carry out religious activities that resemble religious activities of the religion, which interpretations and activities are deviated from the religious teachings.

To prove that there is actus reus and mens rea in a criminal act that refers to Article 1 of Law Number 1/PNPS/1965, specifically that are related to the elements of interpretation and activities that deviate from the points of religious teachings, a judge must ask for information from the religious experts such as scholar and/or Ministry of Religion, which have a tendency towards certain religious groups. In this case, information from religious experts or religious groups is needed. ${ }^{36}$ According to Article 186 of the Criminal Procedure Code, the statement of an expert witness is what an expert stated in a court session.

Based on the Constitutional Court Decision that blasphemy has been declared a criminal offense. The law is not contrary to the 1945 Constitution because it is still applicable and ensnares anyone suspected of doing so. The Court Decisions Number 140/PUU-VII/2009 and Number 84/PUU-X/2012 related to the material testing of Article 156a of the Criminal Procedure Code, in conjunction with the Law Number 1/PNPS of 1965 concerning Prevention of Religious Abuse and/or Blasphemy, which essentially stipulates Religious Blasphemy regulated by Presidential Decree, declare the regulation still valid with consideration to maintaining public order and protection of religious teachings. According to Indrayana ${ }^{37}$, the core of the Constitutional Court's decision is to reject the argument that the offense of

34 Jan Remmelink, Hukum Pidana Komentar atas Pasal Terpenting dari KUHP Belanda dan Padanannya dalam KUHP Indonesia, Jakarta: Gramedia, 2003, pp.85-86.

35 The statement of Andi Hamzah in the case Number 140/PUU-VII/2009.

36 Mien Rukmini, Perlindungan HAM Melalui Asas Praduga Tidak Bersalah dan Asas Persamaan Kedudukan Dalam Hukum Pada Sistem Peradilan Pidana Indonesia, Bandung: Alumni, 2007, p. 137.

37 Ahmad Jazuli, op.cit., p. 339. 
blasphemy is a form of state intervention in the area of religious freedom. The Constitutional Court still believes that religious freedom needs to be restricted, so as not to cause defamation. What is certain is that since the reform era, when freedom of speech became more open, more cases of blasphemy took place. In the New Order era until the beginning of the reform era (1965 to 2000), Article 156a was only used 10 times. However, in the last 15 years (2000 to 2015) it has been used in more than 50 cases. The majority of the perpetrators are Christians (61) and Muslims (49). There are also four cult followers and six people of unknown religious affiliation. It can be concluded that the law on the prevention of blasphemy is necessary to prevent clashes, horizontal conflicts, unrest, division, and hostility in society. religious freedom needs to be limited by law.

\section{Acts and Formulation of Religious Blasphemy offenses in the Draft of Criminal Code}

The renewal of criminal law regarding blasphemy offenses through the new Draft of Criminal Code is criminal law politics. According to Sudarto ${ }^{38}$, the Politics of Law are as follows.

a. It is efforts to realize good regulations in accordance with the situation and condition at a time.

b. It is a policy of the state through the authorized bodies to determine the desired regulations that are expected to be used to express what is contained in the life of the people and to achieve what they aspire.

Implementing criminal law politics means holding elections to achieve the results of criminal legislation that are best in the sense of meeting the requirements of justice and usability. Implementing criminal law politics means an effort to realize criminal legislation that is in accordance with the situation and condition at a time and for the future.

According to Atmasasmita ${ }^{39}$, Pancasila is a value system and a determiner of the development policies and programs of the national legal system. The legal character of the Indonesian people is reflected in the five principles of the Pancasila. At present, the legal orientation as a value system originating from the Pancasila as the foundation of the Indonesian ideology is a guarantee of the Indonesian integrity and the unity in entering the current era of globalization. In the development of $21^{\text {st }}$ century society, the character of Indonesian Criminal Law must cling to the Pancasila and must consider the political direction that can maintain and achieve order, certainty, justice, benefit, and restoration of relations between perpetrators, victims, and society.

The character and political direction of national criminal law has the ultimate goal of justice and is seen in accordance with the Pancasila as the life philosophy of the Indonesian people. Therefore, the renewal of Criminal Law regarding blasphemy offenses should be focused to achieve the results of criminal legislation that best

38 Barda Nawawi Arief, Kebijakan Hukum Pidana...., op.cit., p. 26.

39 Romli Atmasasmita, Rekonstruksi Asas Tiada Pidana Tanpa Kesalahan, Jakarta: Gramedia, 2017, p. 94-95. 
meets the requirements of justice and usability, in accordance with the situation and condition at a time and for the future. It should be disclosed to seek or to make and to formulate a good criminal legislation as proposed by Sudarto.

The renewal of criminal law regarding blasphemy offenses in the $2015 \mathrm{draft}$ of the Criminal Code should follow the views expressed by Sudarto and Atmasasmita. First, the draft places the acts of blasphemy in a separate chapter, Chapter VII (Criminal Actions against Religion and Religious Life). In the current Criminal Code, the acts of blasphemy are included in Chapter V (Crimes against Public Order). In the first part of the draft, three (3) articles formulate Crime against Religion. The three articles regulate the prohibition of insulting religions in Indonesia and incites, in any form, with the intention of removing beliefs in a religion that are adopted in Indonesia. The threat of imprisonment starts from two (2) to five (5) years, revocation of certain rights, and penalties with category $\mathrm{II}^{40}$ and $\mathrm{IV}^{41}$.

Second, in the second part of the Chapter VII, three (3) articles formulate Criminal Actions on Religious Life and Worship Facilities. The three articles regulate the prohibition of disturbing, obstructing, or against the law, dissolving by means of violence, or threats of violence against worshipers who are performing worship, religious ceremonies, or religious gatherings, making noise near a building of worship at the time of worship, insulting people who are carrying out worship or insulting religious officers who are carrying out their duties, tarnishing or illegally damaging or burning buildings of worship or objects used for worship. The threat of imprisonment starts from two (2) years to five (5) years, and criminal fines with category $\mathrm{II}^{42}$, category III, and category IV.

Article 1 of Law Number 1/PNPS of 1965 should be improved not to ensnare cult believers. Adherents of these beliefs must get recognition from the state so that they do not have the potential to tarnish any religion in Indonesia. Believers now get recognition based on the Constitutional Court Decision Number 97/PUU-XIV/2016, which allows the cult followers to write their beliefs on the KTP. Article 2 and Article 3 of the Law Number 1/PNPS of 1965 require the government, namely the Minister of Religion together with the Minister/Attorney General and the Minister of Home Affairs, or by the President of the Republic of Indonesia, to control the flow of cults that did not receive recognition from the state. Article 4, which becomes Article 156a of the Criminal Code, needs to redefine the forms of hostility, abuse, or desecration of a religion embraced in Indonesia, invitation not to adhere to any religion.

The National Alliance of Criminal Reform's research team proposes criticism. They observe a number of religious offenses in the new draft of Criminal Code. It appears that there are no significant changes in the new draft, besides adding some developments regarding human rights and extending articles from the previous Criminal Code. Thus, in terms of the paradigm, no significant in the new draft regarding religious issues. In fact, there is a tendency to strengthen the paradigm

40 See footnote (1).

41 See footnote (2).

42 See footnote (3). 
that has been built in the Criminal Code. The new draft is accused leading to overcriminalization. For instance, Article 342 of the 2005 and 2013 new draft of Criminal Code outlines that the purpose of insulting religion is to insult God's majesty, words, and nature. All these terminologies require interpretation for what is meant by majesty, words, and the nature. What are actions or activities that insult the majesty of God? If there are people who complain to God because they feel God is not fair, do they fall into the category of committing crimes against religion? What if there is pressure or mass action in the name of the articles in the Criminal Code? ${ }^{43}$ These criticisms must be followed up by involving religious leaders from all religions such as the Indonesian Ulama Council (MUI). There have no mediation and dialogue yet accommodated in the Criminal Code. Mediation and dialogue are very possible for a shift in the religious views of the perpetrators. If what happens is a misunderstanding, the perpetrator has no intention or intentional conduct of blasphemy, mediation and dialogue will clarify allegations. Mediation and dialogue are in accordance with the character and political direction of the current national criminal law.

The National Criminal Code Reform Alliance added in its statement that, in the event of a more-abstract-context defamation, the fact that the concept of God in each religion is different, so does the concept of prophet and apostle, the understanding of gods and goddess. Who has the authority to determine them? It is feared that there will be a return to the judgment of the masses who feel the majority. ${ }^{44}$ Therefore, the involvement of religious leaders in cases of blasphemy is a necessity for mediation and dialogue. The mediation step is considered to be more intelligent for the community in responding to religious thinking, encouraging constructive communication between various parties, and respecting the freedom of religion and belief. Seeing the urgency for resolving allegations of blasphemy cases, the mediation and dialogue in the future need to be amended in the Criminal Code, so that it is not only an option, but a part of the steps to resolve blasphemy cases.

Article 342-344 of the new draft of Criminal Code contains multi-interpretive words that even can be interpreted narrowly and unilaterally by bureaucracy, ruler, and mainstream religious elite (for example, the terms defamation, tarnishing religion embraced in Indonesia, God's majesty, words, nature, apostles, and scriptures). In this case, the criminal law must be able to guarantee the enforcement of human rights through respect for the fulfillment of freedom of religion or belief through the guarantee that everyone has the right to practice religion. The criminal law should also exist when the party that obstructs freedom of religion is not in an artificial and abstract meaning regarding blasphemy or humiliation. ${ }^{45}$ These criticisms have been answered through the Decision of the Constitutional Court Number 140/PUU-VII/2009 that the existence of the Blasphemy Prevention Law

\footnotetext{
Emershon Yuntho, op.cit., p. 30.

Ibid.

45 Emershon Yuntho, op.cit., p. 33.
} 
does not prohibit someone from interpreting a religious teaching or conducting religious activities that resemble a religion adopted in Indonesia individually. The prohibition covers intentionally publicly telling, advocating or seeking public support, to make interpretations of a religion embraced in Indonesia or to carry out religious activities that resemble religious activities of the religion, which interpretations and activities are deviated from the religious teachings (Article 1 of the Blasphemy Prevention Act). If this is not regulated, it is feared that it can cause clashes, horizontal conflicts, unrest, division, and hostility in society.

The Blasphemy Prevention Law does not limit one's beliefs. It only limits the statement of thoughts and attitudes according in public. It is especially for the idea that deviates from the mainstream of religious teachings adopted in Indonesia, issuing feelings or acts that are principally hostile, abuse, or desecration against a religion adopted in Indonesia. Therefore, the new draft of Criminal Code is also designed to limit the statements of mind and attitudes in public that deviate from the mainstream teachings of the religions adopted in Indonesia.

Barda Nawawi revealed the reasons that raise fears that the new draft of Criminal Code may lead to over-criminalization or excessive criminalization due to the inexistence of evaluation of the effect on the entire system. ${ }^{46}$ The issue of proselytism of religion to others who already have religions is one of the complex problems in relation to the problem of "religious harmony". However, this action is not regulated in the new draft of Criminal Code. In fact, the protection of harmony in religious life is one of the rationales of religious offenses. The theory of Friedensschutz Theorie (the theory of peace protection of the peace of the religious community) by Oemar Seno Adji explains it.

The new draft of Criminal Code does not contain explicit formulation of proselytism of religion to others who already have religions. In the new draft of Criminal Code, there is only Article 345 on "incitement to exclude belief in religion". The first part on criminal acts against religion regulates it. In this article, it is emphasized that what is prohibited is "inciting in any form". Therefore, it can be questioned whether religious proselytism to other religious people can be included here. The term "incitement in any form" is actually quite extensive, so that if a proselytism is intended so that other people do not believe/trust the religion they adhere to, then such things can actually be included in Article 345. Article 345 of the new draft of Criminal Code requires "in public" and it is not easy to apply in that case because these actions are rare or even difficult to do in public. ${ }^{47}$

Article 346-348 of the new Draft of the Criminal Code provides protection of religious practice from disturbance, mockery, obstruction or, by against the law, dissolve of people who are undergoing worship, religious ceremonies, destruction of places of worship, and so on. In practice, religious offenses, such as damaging places of worship, schools, residential, or mistreatment of followers of certain religions or

46 Barda Nawawi Arief, Bunga Rampai Kebijakan Hukum Pidana, Perkembangan Penyusunan Konsep KUHP Baru, Jakarta: Kencana Prenada Media Group, 2008, p. 30.

47 Barda Nawawi Arief, Delik Agama dan Penghinaan Tuhan (Blasphemy) di Indonesia dan Perbandingan Berbagai Negara, Semarang: Badan Penerbit Universitas Diponegoro, 2010, p. 18. 
beliefs, are dominated by the mainstream. Most of these actions are left unchecked and never handled by law enforcement officers. Cases of destruction of houses of worship and persecution of religious minorities or leaders usually end in the closure of places of worship that have been damaged due to not obtaining permission. ${ }^{48}$

The new draft of Criminal Code should accommodate the role of religious leaders in the event of blasphemy, as well as a criminal offense against religious life and means of worship. Religious leaders understand religious understanding of the God concept and how to carry out religious teachings in matters of worship better than anyone. The involvement of religious leaders such as the MUI through mediation and dialogue has not been accommodated in the new draft of Criminal Code. The involvement of religious leaders to mediate the suspected blasphemers and victims should be the first step that must be taken before bringing the case of blasphemy to the law enforcement process. Mediation and dialogue are very possible for a shift in the religious views of the perpetrators. If the case is only a misunderstanding, the perpetrator has no intention or intentional conduct of blasphemy, mediation and dialogue will clarify allegations.

In essence, the formulation of Religious Blasphemy in the new draft of Criminal Code has not answered the problem regarding the criteria and measures of the acts of Blasphemy to revise the Law Number 1/PNPS of 1965. Some of the criticisms concern about the occurrence of conflicts among religious believers in Indonesia. The renewal of the concept of crime against religion must be based on the Decision of the Constitutional Court Number 140/PUU-VII/2009 that limits to statement of thoughts and attitudes according to their conscience in public that deviates from the mainstream teachings of the religions adopted in Indonesia. Article 1 of the Law Number 1/PNPS of 1965 should be improved not to ensnare cult believers in the Criminal Code. Adherents of these beliefs are beliefs that get recognition from the state so that they do not have the potential to tarnish any religion in Indonesia. Now cult believers get recognition based on the Constitutional Court Decision Number 97/PUU-XIV/2016 that allows them to write their belief on the KTP. Article 2 and Article 3 of the Law Number 1/PNPS of 1965 require the government, namely the Minister of Religion together with the Minister/Attorney General and the Minister of Home Affairs, or by the President of the Republic of Indonesia, to control the flow of cults that did not receive recognition from the state. Article 4, which becomes Article 156a of the Criminal Code, needs to redefine the forms of hostility, abuse, or desecration of a religion embraced in Indonesia, invitation not to adhere to any religion.

The blasphemy cases of Ahok and several previous perpetrators should be answered by the formulation of blasphemy in Chapter VII (Criminal Actions against Religion and Religious Life) and involvement of religious leaders. The formulation must also be in accordance with the political direction of national criminal law that the ultimate goal is to bring peace.

48 Emershon Yuntho, op.cit., p. 34. 


\section{Conclusion}

The urgency to renew the concept of religious blasphemy in the Criminal Code is to answer the issues of blasphemy, which are increasingly prevalent in Indonesia. Article 156a of the Criminal Code that has been existed for the last 15 has been used in more than 50 cases. In 2016, Article 156a of the Criminal Code became more popular with the blasphemy case of Ahok. Arrangement of blasphemy crimes in Law Number 1/PNPS of 1965 must be refined in the new draft of Criminal Code with the basic principle of adhering to the first principle of Pancasila, namely Belief in the One and Only God. The state must view religion as a legal interest that must be protected. The basic paradigm used is Indonesia as a godly state and has a divine philosophy that originates from a very high religious feeling of Indonesian people. The renewal of the blasphemy crime concept must also bridge the fundamental needs in the problem of regulating religious offenses, namely pluralistic administrative order, a sense of diversity, and religious interests. The issue of blasphemy is very sensitive in Indonesia. The problem of blasphemy that is increasingly prevalent in Indonesia is a very valuable lesson to be answered through the penal reform, especially by paying attention to the diversity of the Indonesian people and the Unitary State of the Republic of Indonesia which was built on the motto of Bhinneka Tunggal lka.

The renewal of the criteria and measures of blasphemy in the new draft of Criminal Code must be oriented to the approaches of criminal law policies and values. The form of re-conception and revitalization of blasphemy is to improve Article 1 of the Law Number 1/PNPS of 1965 should not ensnare cult believers in the Criminal Procedure Code. Adherents of these beliefs are beliefs that get recognition from the state so that they do not have the potential to tarnish religion in Indonesia. Article 2 and Article 3 of Law No. 1 PNPS in 1965 involving the government, namely the Minister of Religion together with the Minister / Attorney General and Minister of Home Affairs or by the President of the Republic of Indonesia to control the flow of beliefs that did not receive recognition from the state must be adopted in the new Draft of the Criminal Code. Article 4 which becomes Article 156a of the Criminal Code needs to re-form the forms of hostility, abuse or desecration of a religion embraced in Indonesia, inviting other people not to adhere to any religion.

The blasphemy cases, which are increasingly occurring, and reached its culmination with blasphemy by Ahok, should be answered by refining the formulation of blasphemy in the new draft, especially in Chapter VII (Criminal Actions against Religion and Religious Life). It should also involve religious leaders in their formulation and must be in accordance with current legal politics of criminal law with the ultimate goal of peace. The law is in accordance with Pancasila as the life philosophy of the Indonesian people. The role of religious leaders must be stated in the Criminal Code when a case of blasphemy occurs. The path of mediation and dialogue should be the first step before the law enforcement process is carried out through the criminal justice system. 


\section{References}

\section{Books}

Badan Pembinaan Hukum Nasional (BPHN -National Law Development Agency), Naskah Akademik RUU KUHP, BPHN, Jakarta, 2015.

Barda Nawawi Arief, Bunga Rampai Kebijakan Hukum Pidana, Perkembangan Penyusunan Konsep KUHP Baru, Kencana Prenada Media Group, Jakarta, 2008.

-------------------, Delik Agama dan Penghinaan Tuhan (Blasphemy) di Indonesia dan Perbandingan Berbagai Negara, Badan Penerbit Universitas Diponegoro, Semarang, 2010.

KUHP Baru, Kencana, Jakarta, 2008.

Perbandingan, PT Citra Aditya Bakti, Bandung, 2011.

Edward O.S Hiariej, Membangun Sarana dan Prasarana Hukum yang Berkeadilan, Komisi Yudisial Republik Indonesia, Jakarta, 2012.

Emerson Yuntho (et.al.), Dinamika Pembaharuan KUHP dan Problematikanya, ELSAM \& Aliansi Nasional Reformasi KUHP, Jakarta, 2007.

Endang Saifuddin Anshari, Piagam Jakarta 22 Juni 1945 dan Sejarah Konsensus Nasional, Penerbit Pustaka Salman ITB, Bandung, 1981.

Jimly Asshiddiqie, Gagasan Konstitusi Sosial, LP3ES, Jakarta, 2015.

2005.

Mien Rukmini, Perlindungan HAM Melalui Asas Praduga Tidak Bersalah dan Asas

Persamaan Kedudukan Dalam Hukum Pada Sistem Peradilan Pidana Indonesia, Alumni, Bandung, 2007.

Mohamad Sinal, Pancasila Konsensus Negara-Bangsa Indonesia, Madani, Malang, 2017.

Mudzakir (et.al.), Analisis dan Evaluasi Undang-Undang Nomor 1/PNPS Tahun 1965 Tentang Pencegahan Penyalahgunaan Dan/ Atau Penodaan Agama, Kementerian Hukum dan HAM, Jakarta, 2011.

Remmelink, Jan, Hukum Pidana Komentar atas Pasal Terpenting dari KUHP Belanda dan Padanannya dalam KUHP Indonesia, Gramedia, Jakarta, 2003.

Romli Atmasasmita, Rekonstruksi Asas Tiada Pidana Tanpa Kesalahan, Gramedia, Jakarta, 2017.

Soerjono Soekanto dan Sri Mamuji, Penelitian Hukum Normatif Suatu Tinjauan Singkat, Raja Grafindo Pustaka, Jakarta, 2006.

\section{Other Documents}

Ahmad Jazuli, "Penyelesaian Konflik Penodaan Agama Dalam Perspektif Hukum Pidana Di Indonesia", Jurnal De Jure, Vol. 17, Issue 3, 2017.

Barratut Taqiyyan Rafie, "Akomodasi putusan MK, penganut aliran kepercayaan akan dapat KTP khusus",https://nasional.kontan.co.id/news/akomodasi-putusan- 
mk-penganut-aliran-kepercayaan-akan-dapat-ktp-khusus, accessed on November 2018.

David Oliver Purba, "Mengapa Ahok Ajukan PK atas Vonisnya?", https://megapolitan.kompas.com/read/2018/02/26/05491211/mengapa-ahokajukan-pk-atas-vonisnya, accessed on March 2018.

David Oliver Purba, "PK Ahok Ditolak MA", https://megapolitan.kompas.com/read/2018/03/26/16581111/pk-ahok-ditolakma, accessed on March 2018.

Dieqy Hasbi Widhana, "Asal-Usul Delik Penistaan Agama", https://tirto.id/asal-usuldelik-penistaan-agama-b49e, accessed on November 2018.

Hwian Christianto, "Arti Penting UU No. 1/PNPS/1965 Bagi Kebebasan Beragama", Jurnal Yudisial, Vol. 6, No. 1, 2013.

Rina Atriana dan Aditya Mardiiastuti, "Hakim: Ahok Merendahkan Surat Al-Maidah 51", https://news.detik.com/berita/d-3496149/hakim-ahok-merendahkan-suratal-maidah-51, accessed on December 2018.

Yantina Debora, "Kronologi Kasus Dugaan Penistaan Agama", https://tirto.id/kronologi-kasus-dugaan-penistaan-agama-b457, accessed on November 2018.

\section{Legal Documents}

The 1945 Constitution of Republic of Indonesia.

Indonesian Criminal Code [Kitab Undang-Undang Hukum Pidana].

Draft of Indonesian Criminal Code [Rancangan Kitab Undang-Undang Hukum Pidana].

Law Number 1/PNPS/1965 on the Prevention of Abuse and/or Blasphemy of Religion [Undang-Undang Nomor 1/PNPS/Tahun 1965 tentang Pencegahan Penyalahgunaan dan/atau Penodaan Agama].

Constitutional Court Decision Number 140/PUU-VII/2009 [Putusan Makhamah Konstitusi Nomor 140/PUU-VII/2009 tentang permohonan Pengujian UndangUndang Nomor 1/PNPS/Tahun 1965 tentang Pencegahan Penyalahgunaan dan/atau Penodaan Agama].

Constitutional Court Decision Number 97/PUU-XIV/2016 [Putusan Makhamah Konstitusi Nomor 97/PUU-XIV/2016 tentang Pengujian Undang-Undang Administrasi Kependudukan].

District Court Decision Number 1537/Pid.B/2016/PN [Putusan Pengadilan Negeri Nomor 1537/Pid.B/2016/PN]. 